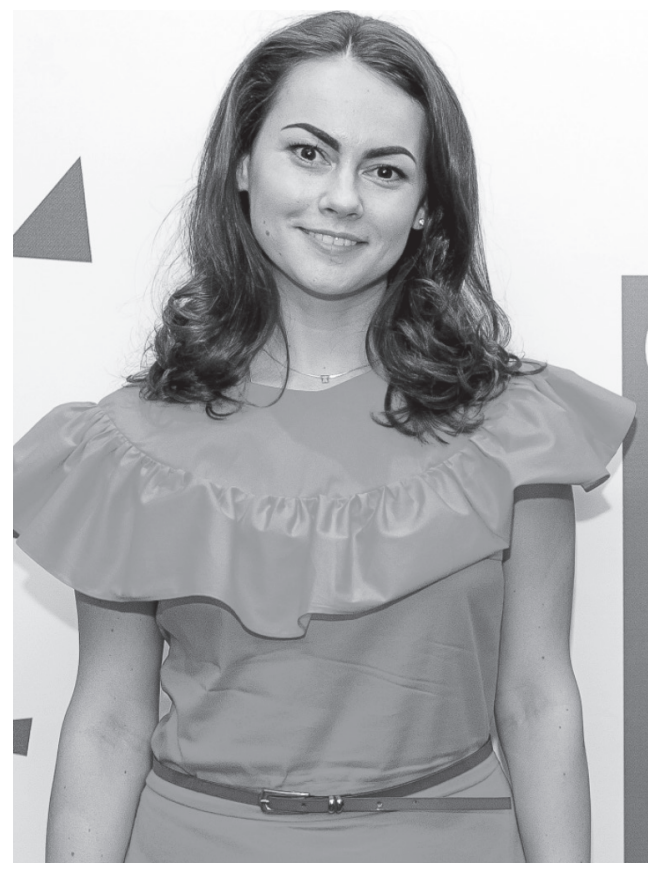
sonnel Management, 03039, Kyiv, Str. Frometivska, tel.: (063)95178 55,e-mail:marusina@ ukr.net

ORCID: 0000-0002-4557-5524

\title{
ІННОВАЦІЙНІ АСПЕКТИ УПРАВЛІННЯ СУЧАСНОЮ ВИЩОЮ ОСВІТОЮ - ВАЖЛИВІША ЗАСАДА УСПІШНОГО ІІЇ РЕФОРМУВАННЯ В ДОБУ ПЕРЕХОДУ ДО СУСПІЛЬСТВ ІНФОРМАЦІЙНОГО ХАРАКТЕРУ
}

Анотація. Аналізуються основні інноваційні аспекти управління сучасною вищою освітою, що зумовлені переходом суспільств від постіндустріального до інформаційного стану. Обгрунтовуються положення, що стосуються: а) характеру і специфіки радикальної модернізації освіти загалом та вищої освіти, безпосередньо; б) роль і значення інновацій в управлінні ЗВО; в) нові підходи до формування державного управління розвитком вищої освіти; г) людський вимір у трансформації вищої освіти та управління нею. Зазначається, що інноваційні зміни у вищій освіті мають неоднозначний характер і можуть класифікуватися за такою системою: а) за реальним рівнем новизни; б) за особливістю їх здійснення (разові, системні, дифузні тощо); в) за станом впровадження (успішні або завершені, незавершені і т. ін.). 
Робиться акцент на тому, що існує чимало різних теорій розвитку освіти в цілому і вищої освіти, безпосередньо: теорія селективного розвитку; теорія ресурсної належності; теорія структурно-ситуативного розвитку; теорія неоінституційного розвитку; феноменологічна теорія та ін. Обгрунтовується теза щодо державного управління вищою освітою як організованої самостійної частини загального процесу державного управління, яке включає розробку, прийняття та практичну рекомендацію організаційних, координаційних, регулюючих, мотиваційних, контролюючих впливів на систему вищої освіти, iї розвиток та прогресивне функціонування. Звертається увага на те, що в процесі аналізу інноваційних аспектів розвитку вищої освіти використовується три можливих теоретико-методологічних підходи: функціональний, технологічний, теоретичний. Обгрунтовано, що “розвиток освіти" - це набагато ширший, об’ємний процес, ніж просто “оновлення освіти”, оскільки завдяки йому освіта набуває якісно нових ознак. Те саме стосується і термінів "модернізація освіти” або “оновлення освіти”, під якими маємо вбачати окремі аспекти освіти.

Ключові слова: освіта, вища освіта, інновації в системі освіти, інноваційні складові трансформації сучасної вищої освіти.

\section{ИННОВАЦИОННЫЕ АСПЕКТЫ УПРАВЛЕНИЯ СОВРЕМЕННЫМ ВЫСШИМ ОБРАЗОВАНИЕМ - ВАЖНОЕ УСЛОВИЕ УСПЕШНОГО ЕГО РЕФОРМИРОВАНИЯ В ПРОЦЕССЕ ПЕРЕХОДА К ОБЩЕСТВАМ ИНФОРМАЦИОННОГО ХАРАКТЕРА}

Аннотация. Анализируются основные инновационные аспекты управления современным высшим образованием, которые обусловлены переходом обществ от постиндустриального к информационному состоянию. Обосновываются положения, которые касаются: а) характера и специфики радикальной модернизации образования в целом и высшего образования, непосредственно; б) роль и значение инноваций в управлении высшими учебными заведениями; в) новые подходы к формированию государственного управления развитием высшего образования; г) человеческий фактор в трансформации высшего образования и управления им. Указывается на то, что инновационные изменения в высшем образовании имеют неоднозначный характер и могут классифицироваться по такой системе: а) по реальным уровням новизны; б) по особенности их осуществления (разовые, системные, диффузные и т. п.); в) по состоянию внедрения (успешные или завершенные, незавершенные и т. д.). Делается акцент на том, что существует немало различных теорий развития образования в целом и высшего образования, непосредственно: теория селективного развития; теория ресурсной принадлежности; теория структурно-ситуативного развития; теория неоинституционного развития; феноменологическая теория и др. Обосновывается тезис относительно государственного управления высшим образованием как организованной самостоятельной частью общего процесса государственного управления, которое включает разработку, принятие и практическую ре- 
ализацию организационных, координационных, регулирующих, мотивационных, контролирующих воздействий на систему высшего образования, его развитие и прогрессивное функционирование. Обращается внимание на то, что в процессе анализа инновационных аспектов развития высшего образования используется три возможных теоретико-методологических подхода: функциональный, технологический, теоретический. Обосновано, что "развитие образования” - это более широкий, объемный процесс, чем просто “обновления образования”, поскольку благодаря ему образование приобретает качественно новые признаки. То же самое касается и терминов “модернизация образования” или “обновления образования”, под которыми можем видеть отдельные аспекты образования.

Ключевые слова: образование, высшее образование, инновации в системе образования, инновационные составляющие трансформации современного высшего образования.

\section{INNOVATIVE ASPECTS OF MANAGEMENT OF MODERN HIGHER EDUCATION - AN IMPORTANT BASIS FOR ITS SUCCESSFUL REFORMATION IN THE ERA OF TRANSITION TO INFORMATIONAL SOCIETIES}

Abstract. The main innovative aspects of management of modern higher education, which are caused by the transition of societies from post-industrial to informational status, are analysed. The article substantiates the provisions concerning: a) the nature and specifics of radical modernization of education in general and higher education directly; b) the role and significance of innovations in the management of institution of higher education; c) new approaches to the formation of public administration in the development of higher education; d) human dimension in the transformation of higher education and its management. It is noted that innovation changes in higher education are ambiguous and can be classified by such a system: a) by the real level of novelty; b) on the peculiarity of their implementation (one-time, systemic, diffuse, etc.); c) in the state of implementation successful or completed, incomplete, etc.). The emphasis is on the fact that there are many different theories of the development of education in general and higher education directly: the theory of selective development; theory of resource membership; theory of structural and situational development; the theory of neoinstitutional development; phenomenological theory and others. The thesis on state administration of higher education as an organized independent part of the overall process of public administration is substantiated, which includes the development, adoption and practical recommendation of organizational, coordinating, regulatory, motivational, controlling influence on the system of higher education, its development and progressive functioning. Attention is drawn to the fact that in the process of analysing the innovative aspects of the development of higher education three possible theoretical and methodological approaches are used: functional, technological, theoretical. It is substantiated that there is every reason to point out that "development of education" is a much wider, voluminous 
process than simply "updating of education", because because of it education acquires qualitatively new features. The same applies to the term "modernization of education", or the term "education update", under which we most likely have to see some aspects of education.

Keywords: education, higher education, innovations in the education system, innovative components of the transformation of modern higher education.

Постановка проблеми. Актуальність проблеми зумовлена незворотністю фактичного революційного характеру трансформацій, притаманних сучасній освіті загалом та вищій освіті, безпосередньо. За усього різноманіття існуючих тут проблем, якісних аспектів, домінує, на нашу думку, той, що пов'язаний з переходом від так званої “знаннєвої” вищої освіти до освіти “діяльнісної. Як зазначає генеральний секретар ОЕСР А. Шляхтер, світова економіка більше не платить вам за те, що ви знаєте, адже Google знає все. Вона платить вам за те, що ви можете робити 3 тим, що знаєте. Серед усіх аспектів радикальних трансформацій вищої освіти, управління нею, особливо державою, в сучасну епоху переходу до інформаційних суспільств на одне 3 найпомітніших місць вийшли інновації. Чим вони зумовлені, якими вони $€$, в чому їх специфіка щодо вищої освіти, що являють собою інноваційні засоби і технології, в чому полягає особливість їх використання, - перелік таких питань можна продовжувати. Загалом виникає реальна потреба предметнішого осмислення і теоретичного опрацювання перелічених та інших питань і проблем, що суттєво посилює актуальність даної проблеми.
Аналіз останніх публікацій. Питання інноваційного розвитку та інноваційного управління вищою освітою достатньо предметно опрацьовується і розробляється сьогодні такими зарубіжними вченими, як М. Барбер, Н. Н. Беннет, К. Робінсон, М. Фуллан, М. Яворська, а вітчизняними - В. Андрущенко, М. Бойченко, М. Гансоном, М. Головатим, Л. Даниленко, С. Калашніковою, В. Кременем, В. Луговим, Ю. Молчановою, Н. Протасовою, А. Сименець-Орловою, А. Струєвою, С. Семенюк, C. Терепищим, Б. Чижевським, М. Шевченко та ін. Акцентуємо увагу на тому, що здебільшого у спеціальних роботах на зазначену тематику чинне місце посідають питання політико-правових змін у країнах, що активно позначаються на розвитку вищої освіти, організаційно-управлінських аспектах, завдяки яким вдосконалюється функціонування вищої освіти тощо. Однак менш опрацьованими залишаються питання сутності та характеру інноваційних складових розвитку вищої освіти та управління нею 3 використанням інновацій, насамперед таким основним суб'єктом, як держава.

Мета статті - розглянути та проаналізувати основні інноваційні аспекти державного управління су- 
часною вищою освітою, адекватно особливостям ㄲi розвитку та суспільної трансформації.

Виклад основного матеріалу. Вочевидь, починати слід з того, аби досить чітко окреслити сутність, сенс, зміст радикальних змін, що мають місце у сучасній вищій освіті, у тому числі і в Україні.

"Розвиток освіти", за визначенням української дослідниці I. Ceменець-Орлової, - це “незворотні, векторні зміни освіти, суттєві оновлення, перехід до якісного нового стану з новими освітніми інтересами, цілями, змістом, структурою, політико-управлінськими механізмами при одночасному знятті застарілих атрибутів освітньої організації, що вичерпали своє функціональне навантаження: складний процес взаємодії прогресивних i регресивних компонентів освіти з суттєвим пріоритетом прогресу" [1, с. 69]. Як бачимо, серед складників цього неоднозначного процесу значне місце посідають “політично-управлінські механізми”. До таких механізмів ми відносимо: а) державну політику в галузі освіти; б) державне управління освітою; в) організаційно-управлінські механізми.

Зміни, інновації у вищий освіті мають різний i неоднозначний характер щодо їх сутнісних особливостей. Так, американський дослідник М. Генсон виокремлює три основні типи таких змін: заплановані, раптові та еволюційні [2, с. 313-314]. Заплановані зміни - це завчасно осмислені, певною мірою прогнозовані зміни, що заздалегідь зрозумілі для учасників управлінського процесу. Раптові - менш очікувані і тому не завжди є осмисленими i результативними. Еволюційні зміни, зазвичай, найбільш причинновідповідні, логічні, хоча й отримувані результати від їх здійснення не завжди є достатньо виправданими. Також M. Генсон виокремлює ще й примусові зміни, здійснення яких не завжди є очікувано-результативним.

Доречно класифікувати зміни у вищій освіті за такою системою: а) зміни за рівнем своєї новизни. Вони можуть бути вирішальними (радикальними) але й менш вагомими (другорядними), а то і взагалі ординарними; б) зміни за особливістю здійснення (разові, системні, дифузні тощо); в) зміни за станом впровадження (успішні, або завершені; незавершені) тощо.

Освітні зміни, реформи нині мають місце фактично у більшості суспільств, однак не скрізь вони дають бажаний ефект. М. Фуллан, зокрема, вказує на те, що успіх здійснення реформ можна оцінювати за такою формулою:

$$
E=M C A,
$$

де $E$ - коефіцієнт корисної дії системи; $M-$ мотивація системи до реформ; $C$ - здатність до реформ; $A$ - підтримка, покликана на певну відповідальність [3, 4]. При цьому доречним є зауваження I. Ceменець-Орлової у тому плані, що “досвід розвинутих країн засвідчив, що освітня галузь прогресувала синхронно з політичними змінами в урядуванні, які призвели до економічної конкурентоспроможності, прозорості та добробуту суспільства" [1, с. 9]. Такий висновок сповна стосується i вищої освіти в колишній та сучасній Україні. 
Існує чимало різних теорій розвитку освіти загалом, серед яких найпопулярнішими $є$ : теорія селективного розвитку (Х. Олдрич, М. Хеннан); теорія ресурсної належності (Г. Селенсік); теорія структурно-ситуаційного розвитку (П. Ядуренс); теорія неоінституціального розвитку (Дж. Маєр); феноменологічна теорія (Б. Хайнінгс). Водночас $є$ всі підстави погодитися з думкою С. Терепищого, який вважає, що “у постіндустріальну (інформаційну) добу зменшується можливість точних розрахунків процедурних аспектів освітніх змін, стає менш зрозумілим, які саме оптимізаційні заходи для цієї системи слід здійснювати в конкретний момент часу” [5, с. 9]. Ці теорії при аналізі інноваційних процесів у вищій освіті слід обов'язково брати до уваги.

У системі освіти є три основні суб'єкти - людина (особистість), держава, суспільство, які нині мають бути фактично рівноправними партнерами, а тому і управління освітою, у тому числі вищою, повинно мати державно-громадянський характер. Це основа не просто демократизації освіти, але її подальшого інтенсивного інноваційного розвитку.

Державне управління вищою освітою, на нашу думку, - це організована самостійна частина загального процесу державного управління, що включає розробку, прийняття та практичну рекомендацію організаційних, координаційних, регулюючих, мотиваційних, контролюючих впливів на систему вищої освіти, іï розвиток та прогресивне функціонування. Засоби, важелі, стимули, методи, завдяки яким держава впливає на освіту, - iï функціонування, розвиток, вдосконалення, і становлять державну систему управління у сфері освіти [6, с. 5].

Багато фахівців у галузі управління освітою вживають термін “управління інноваційно-освітньою діяльністю”. Так I. Семенець-Орлова під цим терміном розуміє "інструментальну галузь сучасного управління, що включає адміністративно-розпорядчі, організаційно-економічні і соціально-психологічні форми та методи ефективного оновлення підготовки висококваліфікованих спеціалістів" [9, с. 70]. 3 цим можна погодитися.

Коли йдеться про інновацію в освіті, як таку загалом, то користуються одним з трьох основних підходів до розуміння іiї сутнісних особливостей:

a) функціональний підхід. Мається на увазі цілеспрямована зміна, завдяки якій освіта набуває принципово нового стану (А. Пригожин);

б) технологічний підхід. Йдеться про певні технолого-економічні дії, діяльнісний процес (Б. Санто);

в) теоретичний підхід. Інноваціїце цілеспрямований, науково-обгрунтований керований процес, що передбачає розв'язання якоїсь конкретної проблеми (Дж. Сорос) [7].

Інновації в освіті - складний і неоднозначний феномен. На думку відомого українського освітянина В. Кременя, існує понад 100 різних дефініцій інновацій [8]. Нагадаємо, що в Законі України "Про інноваційну діяльність" інноваціями визнаються ті дії, що істотно поліпшують будь-яку сферу, виробництво тощо [9]. При цьому акцентуємо увагу на 
тому, що для сфери вищої освіти, в якій би країні вона не реформувалася, людський вимір (попри технологіi, організаційні засади, інноваціі) був і залишається вирішальним. Роль людини, лідера в реформуванні освіти досліджували і досліджують В. Андрущенко, Н. Беннетті, М. Барбер, М. Головатий, Д. Гопкіна, В. Кремень та багато інших вчених у світі та Україні.

Чимало вчених, зокрема в Україні - М. Багатченко, Л. Даниленко, С. Калашнікова, А. Сбруєва та інші детермінують, пише I. Семенець-Орлова, феномен лідерства в освіті як нову управлінську парадигму [1, c. 159].

3 поміж багатьох проблем управління сучасною освітою, виокремимо саме проблему підготовки керівників сфери освіти. Йдеться, зазначають Н. Протасова, Ю. Молчанова, не тільки про “спрямованість на послідовне удосконалення знань, а й на розвиток особистісної сфери управлінців, мотивацію безперервного професійного самовдосконалення та самоосвіти” [10, с. 216-217].

Висновки. Інноваційний розвиток вищої освіти, i. радикальна трансформація адекватно потребам соціального прогресу суспільств - явище об'єктивно-закономірне. Одночасно такі трансформації потребують і змін у системі державного управління вищою освітою, змін в управлінні 3 ВО безпосередньо на інноваційних засадах. Більш глибоке переосмислення цих проблем дасть змогу вибирати i ефективніше використовувати новіші, прогресивніші способи, методи, технології, які розробляються у суспільствах перехідного, інформацій- ного стану, яким є і українське суспільство сьогодні.

\section{СПИСОК ВИКОРИСТАНИХ ДЖЕРЕЛ}

1. Семенець-Орлова I. А. Державне управління освітніми змінами в Україні: теоритичні засади: монографія / І. А. Семенець-Орлова. - К.: ЮСПТОН, 2018. - 42 c.

2. Гансон М. Керування освітою та організаційна поведінка / М. Гансон. Л.: Літопис, 2002. - 413 с.

3. Фуллан М. Сили змін. Вимірювання глибини освітніх реформ / М. Фуллан. - Л.: Літопис, 2008. Ч. $1 .-271 \mathrm{c}$.

4. Фуллан М. Сили змін. Вимірювання глибини освітніх реформ / М. Фуллан. - Л.: Літопис, 2008. Ч. 2 (Продовження). -164 с.

5. Терепищий С. Сучасні освітні ландшафти / С. Терепищий. - К.: Фенікс, 2016. - 321 с.

6. Державне управління у сфері освіти: глосарій з дисциплін магістерської програми за спеціальністю “Державне управління у сфері освіти” / авт. кол.: Н. Г. Протасова, В. І. Луговий, Ю. О. Молчанова та ін.; за заг. ред. Н. Г. Протасової. - К.: НАДУ, 2013. - 432 c.

7. Власенко О. Інноваційний менеджмент / О. Власенко. - К.: Знання, 2011. - 342 c.

8. Феномен інновацій: освіта, культура: монографія / за заг. ред. В. Кременя. - К.: Педагогічна думка, 2018. - 19 c.

9. Законодавство України у сфері наукової, науково-технічної та інноваційної діяльності (Верховна Рада України. Комітет з питань науки та освіти / М. Шевченко, Б.Чижевський, С. Семанюк та ін. - К.: Парламентське вид-во, 2013. - 28 с. 
10. Реформування освіти в Україні: державно-управлінський аспект: навч.-наук. вид. / Н. Протасова, В. Луговий, Ю. Молчанова та ін.; за заг. ред. Н. Протасової. - К.: НАДУ, 2012. $-321 \mathrm{c}$.

\section{REFERENCES}

1. Semenets-Orlova I. A. (2018). Derzhavne upravlinnia osvitnimy zminamy $\mathrm{v}$ Ukraini: teoretychni zasady [Public Management of Educational Change in Ukraine: Theoretical Principles]. Kyiv: YuSPTON [in Ukrainian].

2. Hanson E. M. (2002). Keruvannia osvitoiu ta orhanizatsiina povedinka [Educational Administration and Organizational Behavior]. Lviv: Litopys [in Ukrainian].

3. Fullan M. (2008). Syly zmin. Vymiriuvannia hlybyny osvitnikh reform [The forces of change. Measuring the depth of educational reform]. (Vols 1). Lviv: Litopys [in Ukrainian].

4. Fullan M. (2008). Syly zmin. Vymiriuvannia hlybyny osvitnikh reform [The forces of change. Measuring the depth of educational reform]. (Vols 2.). Lviv: Litopys [in Ukrainian].

5. Terepyshchyi S. (2016). Suchasni osvitni landshafty [Modern Educational Landscapes]. Kyiv: Feniks [in Ukrainian].
6. Protasova N. H., Luhovyi V. I., Molchanova Yu. O., et al. (2013). Derzhavne upravlinnia u sferi osvity: hlosarii z dystsyplin mahisterskoi prohramy za spetsialnistiu "Derzhavne upravlinnia u sferi osvity" [Public Administration in the Field of Education: Glossary on the Disciplines of the Master's Program in the fild "Public Administration in the Field of Education"]. N. H. Protasova (Eds.). Kyiv: NADU [in Ukrainian].

7. Vlasenko O. (2011). Innovatsiinyi menedzhment [Innovation Management]. Kyiv: Znannia [in Ukrainian].

8. Kremenia V. (Eds.). (2018). Fenomen innovatsii: osvita, kultura [The phenomenon of innovation: education, culture]. Kyiv: Pedahohichna dumka [in Ukrainian].

9. Sherchenko M., Chyzherskyi B., Semaniuk S., et al. (2013). Zakonodavstvo Ukrainy u sferi naukovoi, naukovotekhnichnoi ta innovatsiinoi diialnosti [Legislation of Ukraine in the field of scientific, scientific-technical and innovation activities]. Kyiv: Parlamentske vydavnytstvo [in Ukrainian].

10. Protasova N., Luhovyi V., Molchanova Yu., at al. (2012). Reformuvannia osvity v Ukraini: derzhavno-upravlinskyi aspect [Reform of education in Ukraine: the state-management aspect]. N. Protasova (Eds.). Kyiv: NADU [in Ukrainian]. 